\title{
Korean Drama as Geography's Audio-Visual Learning Media of Disaster Mitigation
}

\author{
Edi Kurniawan*, Danang Junior Trimasukmana
}

Department of Geography, Universitas Negeri Semarang, Indonesia

Received February 6, 2020; Revised March 24, 2020; Accepted March 282020

Copyright $\bigcirc 2020$ by authors, all rights reserved. Authors agree that this article remains permanently open access under the terms of the Creative Commons Attribution License 4.0 International License

\begin{abstract}
The use of audio-visual learning media is one effective way of increasing the effectiveness of learning geography in the classroom. In line with innovative learning using audio visual teaching media, the writer tries to take the type of audio visual teaching media in the form of Korean drama. The background of the use of audio visual teaching media is based on the fact that currently, Korean culture or the Hallyu Wave is in high demand by various groups throughout the world, not least in Indonesia, which significantly influences the lives of young people. This empirical evidence is the influence of Korean drama and music on increasing achievement and effectiveness in the learning process. This study aims to analyze the influences of Korean Drama as audiovisual learning media of students' interest and study result in XI Social grade SMAN 1 Bantarkawung. The researcher collected data using questionnaires, tests, observation letters, and documentation. The data analysis technique used descriptive analysis percentage and simple linear regression analysis. The result of the research showed the student's interest in XI Social 1 is $83,68 \%$ and the study result is $74,48 \%$. The variable of using Korean Drama as audiovisual learning media influences student's interest at $0,673 / 67,3 \%$ and influences the study result at $0,728 / 72,8 \%$. The conclusion of this study is "there is a significant influence between using Korean Drama as audiovisual learning media to of student's interest and study result in XI Social grade SMAN 1 Bantarkawung”.
\end{abstract}

Keywords Audiovisual, Disaster, Korean Drama, Geography, Mitigation

\section{Introduction}

Geography is still considered a boring subject for students. Content or content of geographic material that presents many abstract theories and concepts such as containing consequences requires students to memorize them well. The boring learning model increasingly makes these subjects less attractive to students. Various innovative learning strategies have been implemented, but in operational practice, the learning models are less effective so that many teachers return to using conventional learning models [1].

Student learning interest is influenced by the way students learn. How to learn in learning geography will encourage students to use all five senses [2]. How to learn in geography subjects can be done both indoors and outdoors, so geography learning will be more effective when using appropriate learning models [3].

Learning outcomes are the ultimate goal of implementing learning activities in schools. Learning outcomes can be improved through conscious efforts carried out systematically, leading to positive changes which are then called the learning process [4]. The end of the learning process is the acquisition of student learning outcomes. Learning media is the right solution used to realize enjoyable learning for students because learning media can appreciate the various characteristics and abilities of students. Learning media as an important element in learning because of its function as a teacher's aid in conveying messages and developing students' thinking power, as one example of fun learning media is to use media that is following technological and information advancements that are expected to overcome student's maturation and understanding.

The use of instructional media aims to improve learning outcomes in accordance with 21 st century competency demands. In the 21 st century education paradigm, students must be able to have High Order Thinking Skills (HOTS) consisting of communication, creativity, critical thinking skills, and collaboration. Previously, students were only asked to memorize concepts in learning so that learning was only textual [5]. In the 21 st century learning, students must be able to analyze, evaluate, and create innovations to 
the problems and phenomena around them so that they are not only able to memorize them [6]. To realize HOTS-based learning, instructional media innovation is needed to bring learning material from the abstract realm to be more concrete and contextual.

Audiovisual media, according to Sanjaya[7], is a type of media that in addition to containing sound elements, also includes elements of images that can be seen, for example, video recordings, various film sizes, sound slides, and so forth. Arsyad[8] suggests that the film or images in the frame should be projected through the projector lens mechanically so that the screen looks alive. From these media the teacher can present information, explain the process, explain complex concepts, teach skills, shorten or extend time and influence attitudes.

Pranoto[9] in his research also revealed that geography learning that uses audiovisual learning media had been effectively used in learning, this is evident from the total sample studied, in the tabulation of assessment scores, $67 \%$ of the sample belongs to the very high criteria.

One of the new subject matter contained in the learning of geography in the 2013 curriculum is the subject matter of natural disasters taught in class XI. Disaster according to Law Number 24 of 2007 concerning Disaster Relief is an event or series of events that threaten and disrupt people's lives and livelihoods, both by natural factors and/or non-natural and human factors, resulting in human casualties, environmental damage, property losses, and psychological impacts [10]. Disasters are basically ordinary phenomena that will occur periodically in a region with varying magnitude. Therefore, the existence of disaster education is very crucial case to reduce it's negative impacts [11].

In line with innovative learning using audio-visual teaching media, the writer tries to take the type of audiovisual teaching media in the form of Korean drama, where logically or reason has no relationship at all with learning, especially explicit learning of geography, but explicitly with the help of explanations from the Korean teacher drama with several choices from writers who have elements of learning, especially geography, which are expected to be able to support in achieving learning objectives.

Korean culture is one of the developing and global cultures in this globalization era. The emergence of Korean culture throughout the world is commonly referred to as the Hallyu Wave or Korean Wave, with the most famous products being Drama (K-Drama) and Music (K-Pop). According to Sari [12], the Hallyu Wave is very easily accepted in Indonesian society because of its very intensive distribution via television and the internet, as well as being saturated with Indonesian people with just the same entertainment. Some Korean Dramas have the value of learning geography both from the plot / plot and from the choice of background / setting that supports.

Currently, Korean culture or the Hallyu Wave is in great demand by various groups throughout the world, including Indonesia. Many factors cause Hallyu Wave, especially Korean Drama to be accepted and sought by various groups, especially the younger generation of students in Indonesia, as reported by the website kompasiana.com which mentions six reasons for the interest of Korean Drama in Indonesia, including the quality of the cast or cast, then the suitability of the character played with the role of the player, the soundtrack or accompaniment in the drama is very suitable and commercial, has a bold storyline and tends to be different from the types of drama or soap opera in the world, cinematic display is very good so that spoil the audience and like watching a box office movie in a cinema, and finally the supporting things in the drama are worked out very well by the production team such as extras, castors, and others.

Korean drama refers to television dramas in South Korea, in a mini-series format, and is produced in Korean. In general, there are two main genres in Korean Drama. The first genre is a modern genre that resembles western soap operas with a short, ending plot, and without clear sexual references that are often found in western drama. This genre usually involves conflicts related to human relations, be it love relationships, friends, friendship, work, education, or conflict relationships. This genre usually only has at least ten episodes up to 30 episodes, or even a maximum of up to 100 episodes, with a duration of 50 to 60 minutes per episode and two to three episodes per week.

The second genre is Korean History Drama (also known as saeguk), which is a dramatization of Korean historical fiction. This genre usually involves a very complex storyline with costumes, settings, and special effects that are very complicated. Martial arts, war and horse riding are often major components of this genre. Both the first and second genres are usually characterized by the excellent production quality, character depth, and manuscript maturity

The strength of the Halyu Wave is one of the implications of globalization which is supported by the sophistication of information and communication technology that brings all countries in the world into a global network system hence the whole world has directed to a new world civilization. It is not surprisingly that globalization is also led to negative access to the weakening of local cultural wisdom, the degradation of national characters values, and the unity of the Indonesian people [13]. However, globalization is not always negative, but also can have a big positive impact on the field of science, one of which is in the development of teaching media.

Sou[14] in his research concluded that $62 \%$ of respondents stated that watching Korean dramas greatly influenced them in teaching and learning activities in schools, and about $43 \%$ of respondents stated their learning outcomes and achievements improved because they often watched Korean dramas. Besides, Agatep[15] in his 
research also revealed $69.2 \%$ of the respondents felt more comfortable learning accompanied by Korean Music or Korean Drama, then $81.2 \%$ of respondents said K-Pop influenced them in life, such as in learning, goals goals, daily habits, and social life.

\section{Materials and Methods}

The research location is in SMA Negeri 1 Bantarkawung, Brebes Regency, Central Jawa Province, the population of this study is the entire class XI IPS. This study uses a purposive sampling technique that is sampling by taking subjects not based on strata, random, or region but based on the existence of certain objectives [16]. Samples taken were 61 students from class XI IPS 1 as an experimental class and class XI IPS 2 as a control class. For more details, the status of the sample to be examined can be seen in the following table 1 :

$$
\text { Table 1. The List of Sample }
$$

\begin{tabular}{|c|c|c|c|}
\hline No. & Class & Total of Students & Sample Status \\
\hline 1. & XI IPS 1 & 30 & Experiment Class \\
\hline 2. & XI IPS 2 & 31 & Control Class \\
\hline 3. & XI IPS 3 & 30 & Requirement Class \\
\hline
\end{tabular}

Researchers will research the influence of the use of Korean drama audiovisual learning media on the interests and learning outcomes of students of class XI IPS SMAN 1 Bantarkawung on the subject matter of natural disasters. Sampling is based on special considerations and specific objectives because the study has determined in advance the sample that will be used for research following the research objectives.

Data collection methods use the method of documentation, questionnaires, tests, and observations. The data analysis technique uses percentage description analysis and simple linear regression analysis.

\section{Result and Discussion}

The location of the study was conducted at SMA Negeri 1 Bantarkawung, which is located at Jalan Raya Bantarkawung number 5, Pangebatan Village, Bantarkawung District, Brebes Regency, Central Java.The level of influence of the use of Korean drama audiovisual learning media on student learning interest in Class XI IPS 1 illustrates whether there is an influence of the use of Korean drama audiovisual learning media on the interests and learning outcomes of students, in this case, those carried out in the experimental class namely Class XI IPS 1 with total respondents were 30 students. The data was obtained using a questionnaire instrument sheet to measure learning interest and a test instrument sheet to measure student learning outcomes. In this case, the use of audiovisual learning media Korean Drama is an independent variable $(\mathrm{X})$ and student interest in learning and student learning outcomes are the dependent variable (Y), then analyzed using simple linear regression analysis to measure whether there is influence of the two variables and how much their influence, and use a descriptive percentage analysis to measure the percentage of its effect, but the two dependent variables (Y) are calculated and analyzed separately.

Based on the research data in tables 2 and 3 the results of the calculation of simple linear regression analysis yields a regression equation $\mathrm{Y}^{\prime}=323.09+1.17 \mathrm{X}$ for learning interest, and $46.68+1.15 \mathrm{X}$ for learning outcomes, this shows a positive influence from the independent variable to the dependent variable, it means that there will be an increase in interest and learning outcomes for each use of the Korean Drama audiovisual media.

Meanwhile, in testing the hypotheses between the two variables, yielding $\mathrm{t}$ arithmetic of 0.566 for learning interest and $\mathrm{t}$ arithmetic of 1.24 for learning outcomes where $\mathrm{t}$ table for both is 0.374 which means $\mathrm{t}$ arithmetic $>\mathrm{t}$ table so that the conclusions obtained are the rejection of $\mathrm{H} 0$ that is, there is no effect of the use of Korean Drama audiovisual learning media on students 'interest and learning outcomes and acceptance of $\mathrm{Ha}$ ie there is an influence of the use of Korean Drama audiovisual learning media on students' interest and learning outcomes.

According to other calculations, based on the research data in tables 2 and 3, the results of the calculation of a simple linear regression analysis produce a correlation coefficient of 0.673 and a coefficient of determination of 0.454 for interest in learning, and a correlation coefficient of 0.728 and a coefficient of determination of 0.521 for learning outcomes, which means when linked to the interpretation coefficient interpretation table for both is in the "strong" relationship level interval classification. Correlation coefficient 0.673 means $67.3 \%$ of $100 \%$ of the factors that influence learning interest are the use of Korean Drama audiovisual learning media, the remaining $32.7 \%$ which influences are other factors. Also the correlation coefficient 0.728 means $72.8 \%$ of $100 \%$ factors that influence learning outcomes are the use of Korean Drama audiovisual learning media, the remaining $27.2 \%$ which influence are other factors.

Meanwhile, in the calculation of descriptive analysis of percentages, based on data from research results in tables 2 and 3 the results of the calculation of descriptive analysis of percentages yielded $83.68 \%$ for learning interest and $74.48 \%$ for learning outcomes. Based on these calculations, the learning interest of students in class XI IPS 1 is included in the "very high" category, and student learning outcomes in class XI IPS 1 is included in the "high" category. These results can be seen in the following tables 2 and 3 . 
Table 2.Analysis of Study Interest Calculation

\begin{tabular}{|c|c|c|}
\hline No. & Calculation Result & Study Interest \\
\hline 1. & Coefficient of Correlation $(\mathrm{r})$ & 0,673 \\
\hline 2. & Coefficient of Determination $\left(\mathrm{r}^{2}\right)$ & 0,454 \\
\hline 3. & Regression Formula & $\mathrm{Y}^{\prime}=323,09+1,17 \mathrm{X}$ \\
\hline 4. & $\mathrm{t}$ of table & 0,374 \\
\hline 5. & t of calculation & 0,566 \\
\hline 6. & Hypothesis Result & $\begin{array}{c}\mathrm{H}_{\mathrm{a}} \text { was accepted, } \mathrm{H}_{0} \\
\text { was declined }\end{array}$ \\
\hline 7. & Descriptive of Percentage & $83,68 \%$ \\
\hline 8. & Percentage Criteria & Very High \\
\hline
\end{tabular}

Source: Research Result Data, 2019.

Table 3.Analysis of Study Outcomes Calculation

\begin{tabular}{|c|c|c|}
\hline No. & Calculation Result & Study Outcomes \\
\hline 1. & Coefficient of Correlation $(\mathrm{r})$ & 0,728 \\
\hline 2. & $\begin{array}{c}\text { Coefficient of Determination } \\
(\mathrm{r} 2)\end{array}$ & 0,521 \\
\hline 3. & Regression Formula & $\mathrm{Y}^{\prime}=46,68+1,15 \mathrm{X}$ \\
\hline 4. & t of table & 0,374 \\
\hline 5. & t of calculation & 1,240 \\
\hline 6. & Hypothesis Result & $\begin{array}{c}\mathrm{H}_{\mathrm{a}} \text { was accepted, } \mathrm{H}_{0} \text { was } \\
\text { declined }\end{array}$ \\
\hline 7. & Descriptive of Percentage & $74,48 \%$ \\
\hline 8. & Percentage Criteria & High \\
\hline
\end{tabular}

Source: Research Result Data, 2019.

\section{The Level of Use of Korean Drama Audio Visual Learning Media}

Learning media are tools or intermediaries needed in the delivery of material or information in learning. Learning media in this study only serve as aids or intermediaries for teachers to convey messages in learning, not as explanatory or summarizing material.In this research, the media used is audiovisual media, which is a media that combines aspects of hearing in the form of sound and visual aspects in the form of still images and moving images. Audiovisual media used is Korean Drama, a television program from South Korea that is selected and sorted by researchers so that the content aired in learning is following the material presented.

In this study, the media is only used in the experimental class XI IPS 1 class, whereas for the control class XI IPS 2 class does not use the media. The level of use of Korean Drama audiovisual learning media in class XI IPS 1 was obtained from the observation sheet instrument test results. The observation sheet contains three indicators, namely readability / readability, verbal component, and non-verbal component, each indicator has ten items/questions with two choices of answers, so the total questions/questions in the observation sheet are 30 items.

These results were then analyzed using descriptive percentage analysis, and the result is that the level of use of Korean Drama audiovisual learning media was $85.55 \%$ and included in the "very high" criteria. Meanwhile, for the results of each indicator is $86.3 \%$ for indicators of readability / readability, $78 \%$ for indicators of verbal components, and $92.3 \%$ for indicators of non-verbal components. Based on these results, the use of Korean Drama audiovisual learning media in this study is considered effective, because it has a very high percentage level, where the observation sheet is filled in by the respondents who were subjected to the media in learning. The high results are influenced by the appropriateness and accuracy of the components of the media in their use during research.

\section{The Effect of the Use of Korean Drama Audio Visual Learning Media on Student Learning Interest}

Interest in learning is a sense of preferability and a sense of interest in learning new things or learning activities without coercion and without being instructed [17]. Learning is a student activity to deepen the knowledge of a student. The characteristics of learning activities are characterized by changes in behavior, which can be seen from several factors, one of which is his interest in learning. Interest in learning does not arise by itself, but many factors. These factors include student motives, attention, learning material, and teacher attitudes.

Geography learning is essentially learning about aspects of the surface of the earth, which is the overall natural phenomena and human life with regional variance. Learning geography in this study is the subject of natural disasters, where the subject matter is arguably new because it was only published in the learning of geography in this 2013 curriculum.

Learning interest in this study was obtained from the results of a questionnaire instrument test about learning interest, where the results were analyzed using descriptive percentages analysis and simple linear regression analysis. Indicators of interest in learning sought in these instruments include the readiness of students to receive lessons, the presence of students for those who take part in learning, the ability of students to answer questions, the enthusiasm of students in answering questions, students' attention in learning, students' diligence in doing practice questions, and students' sense of interest in answering questions.

Simple linear regression analysis for learning interest in class XI IPS 1 obtained the results of the correlation coefficient 0.673 so that it included the category of "strong" and the coefficient of determination 0.454, according to the calculation of the determination test in the hypothesis testing showed $t$ arithmetic of 0.566 which is greater than $t$ table of 0.374 which meaning that there is an influence from the use of audiovisual learning media. The results of statistical analysis can be seen in the following table 4. 
Table 4.Statistical Analysis of Study Interest

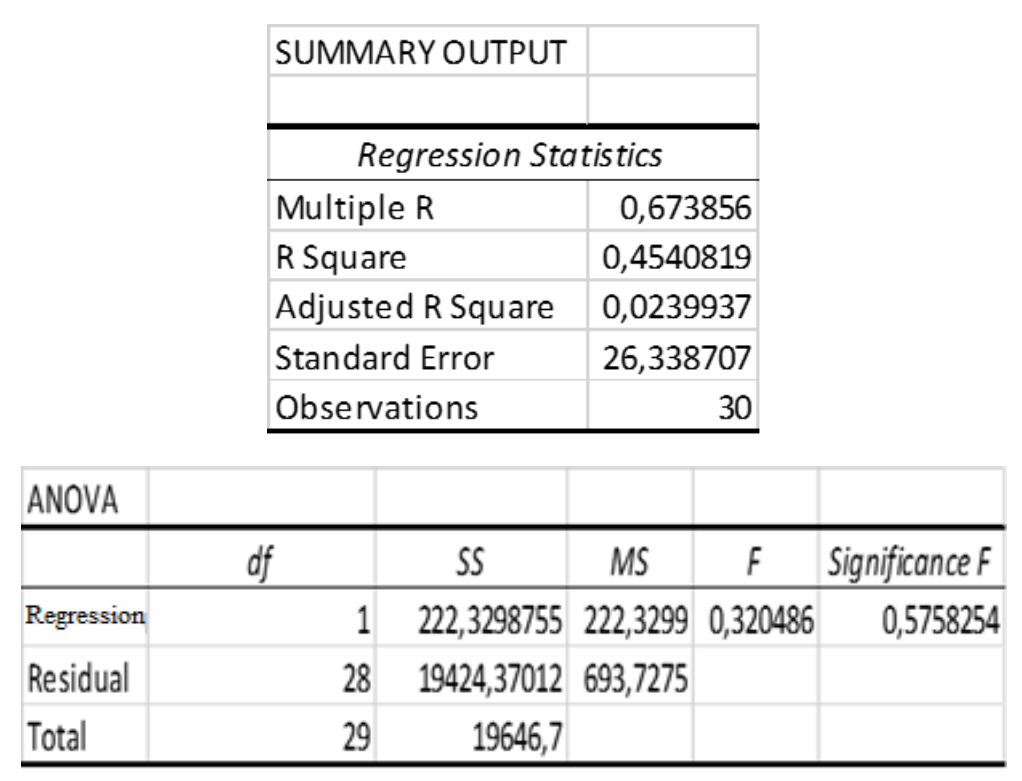

Meanwhile, according to the calculation of the percentage descriptive analysis, the results obtained were $83.68 \%$ and included in the "very high" category. These results indicate the high learning interest of students of class XI IPS 1 in geography. In class XI IPS 2, the results of the calculation of descriptive analysis of the percentage of students' interest in learning amounted to $76.23 \%$ and included in the "very high" category. When compared with the results of the descriptive analysis the percentage of class XI IPS 1, the results of class XI IPS 2, are lower, even having a margin of $7.45 \%$. This shows the level of interest in learning in geography subjects in class XI IPS 2 is lower when compared to the interest in learning in geography subjects in class XI IPS 1.

\section{The Effect of the Use of Korean Drama Audio Visual Learning Media on Student Learning Outcomes}

Learning outcomes are abilities possessed by students after receiving their learning experiences [16]. Learning outcomes are influenced by students' abilities and quality of teaching. In this study, the learning outcomes to be studied are from the cognitive / knowledge domain. Geography learning is essentially learning about aspects of the surface of the earth which is the overall natural phenomena and human life with regional variance. Learning geography in this study is the subject of natural disasters, where the subject matter is arguably new because it was only published in the learning of geography in this 2013 curriculum. The average learning outcomes of geography on the subject matter of natural disasters have increased from the previous academic year which is $\mathbf{5 6 . 9 3}$ to 76.04, and this result has exceeded the Minimum Completeness Criteria (KKM) set of 70 .

Learning outcomes in this study were obtained from the test results of test instruments, where the results were analyzed using descriptive analysis of percentages and simple linear regression analysis. Indicators of geography learning outcomes of natural disaster subject matter sought in the instrument include the types and characteristics of natural disasters, disaster management cycle, distribution of natural disasters, institutions that play a role in disaster management, natural disaster management through education, local wisdom, and the use of modern technology - community in natural disaster mitigation.

Simple linear regression analysis for learning outcomes in class XI IPS 1 obtained the results of the correlation coefficient of 0.728 so that it included the category of "strong" and the coefficient of determination of 0.521, according to the calculation of the determination test in hypothesis testing showed at count of 1.240 which was greater than $t$ table of 0.374 which meaning that there is an influence of the use of Korean Drama audiovisual learning media on student learning outcomes. The results of statistical analysis can be seen in the following table 5 . 
Table 5.Statistical Analysis of Study Outcomes

\begin{tabular}{|l|r|}
\hline \multicolumn{2}{|l|}{ SUMMARY OUTPUT } \\
\hline \multicolumn{2}{|c|}{ Regression Statistics } \\
\hline Multiple R & 0,728259 \\
\hline R Square & 0,521022 \\
\hline Adjusted R Square & 0,018249 \\
\hline Standard Error & 11,82834 \\
\hline Observations & 30 \\
\hline
\end{tabular}

\begin{tabular}{|l|r|r|r|r|r|}
\hline ANOVA & & & & & \\
\hline & $d f$ & \multicolumn{1}{c|}{$S S$} & \multicolumn{1}{c|}{ MS } & \multicolumn{1}{c|}{$F$} & Significance $F$ \\
\hline Regression & 1 & 215,3278 & 215,3278008 & 1,539048 & 0,225054468 \\
\hline Residual & 28 & 3917,472 & 139,9097214 & & \\
\hline Total & 29 & 4132,8 & & & \\
\hline
\end{tabular}

Source: Research Result Data, 2019.

Meanwhile, according to the calculation of the descriptive percentage analysis, the results obtained were $74.48 \%$ and included in the "high" category. These results indicate the high learning outcomes of students of class XI IPS 1 on geography.

The average learning outcomes in the subject matter of natural disasters themselves in class XI IPS 1 has increased by 19.11 points from 56.93 in the $2017 / 2018$ academic year which did not use the Korean Drama The data learning media to 76.04 in the year lesson 2018/2019 which uses Korean Drama audiovisual learning media (details attached), meanwhile for the average learning outcomes in class XI IPS 2 that do not use Korean Drama audiovisual learning media is 30.24 even lower when compared to learning outcomes in the previous school year. For more details, a comparison of learning outcomes on the subject matter of natural disasters can be seen in Table 6 .

Table 6. The Comparison of Learning Outcomes

\begin{tabular}{|c|c|c|}
\hline Period & XI Social 1 & XI Social 2 \\
\hline $2017 / 2018$ & 56,93 & 56,93 \\
\hline $2018 / 2019$ & 76,04 & 30,24 \\
\hline
\end{tabular}

Source: Research Result Data, 2019.

In class XI IPS 2, the results of the calculation of descriptive analysis of the percentage of student learning outcomes amounted to $30.61 \%$ and included in the category of "low." When compared with the results of the descriptive analysis of the percentage of class XI IPS 1 which amounted to $74.48 \%$, the results of the descriptive analysis of the percentage of class XI IPS 1 were lower.

\section{Conclusions}

The use of Korean drama audiovisual learning media on geography subject matter for natural disasters in class XI IPS 1 based on observations showing positive responses from students, it is seen that when learning takes place, students are very enthusiastic in participating in learning and quite actively playing a role in learning such as when the teacher asks questions or during group discussions. Based on the analysis of the percentage description analysis of the observation sheet instruments filled out by students according to the limits in the discussion of the tools and data collection techniques of the observation section, the use of Korean drama audiovisual learning media that has been carried out in the study belongs to the "very high" criteria $(80 \%-100 \%)$, it can be seen from the average total score obtained by students reaching 25.6 from a total score of 30 .

The use of Korean Drama audiovisual learning media on geography subject matter for natural disasters in class XI IPS 1 influences student learning interest, this is seen from the results of simple linear regression analysis with the regression equation $\mathrm{Y}^{\prime}=323.09+1.17 \mathrm{X}$ and $\mathrm{t}$ arithmetic of 0.566 which is greater than t table of 0.374 , the influence between these variables is also significant, calculated from the correlation coefficient of 0.673 and included in the category of "strong." Meanwhile, the interest in learning from Class XI IPS 1 according to the calculation of descriptive analysis percentages, included "very high" with a percentage value of $83.68 \%$.

The use of Korean Drama audiovisual learning media on geography subject matter of natural disasters in class XI IPS 1 also affects student learning outcomes, this is seen from the results of simple linear regression analysis with the regression equation $\mathrm{Y}^{\prime}=46.48+1,15 \mathrm{X}$ and $\mathrm{t}$ count of 1.240 which is greater than t table of 0.374 . The influence between these variables is also significant, calculated from the correlation coefficient of 0.728 and belongs to the "strong" category. Then the learning outcomes of Class XI 
IPS 1 according to the calculation of descriptive analysis of percentages including "high" with a percentage value of $74.48 \%$. The average student learning outcomes in Class XI IPS 1 has increased from the previous school year, from 56.93 to 76.04 .

\section{Acknowledgements}

This research was condut at SMA N Bantarkawung Brebes Indonesia, so That Thanks very much to all of teacher and students.

\section{REFERENCES}

[1] Zuhra S. Pengaruh media audio visual terhadap aktivitas dan hasil belajar siswa pada materi Sistem Gerakpada Manusia di MAN 1 Pidie. Article : UIN AR-Raniry Darussalam Banda Aceh: 2018

[2] Natakusuma A, Suroso, Hardati P. Pengaruh cara belajar terhadap hasil belajar siswa pada mata pelajaran Geografi di SMA Negeri 2 Pekalongan. Journal of Edu Geography. 2017: 5(3): 124-133.

[3] Kusniana NEK, Rahayuningsih M. Pengaruh pembelajaran Model Think Talk Write materi ekosistem terhadap hasil belajar siswa.Journal of Lembaran Ilmu Kependidikan UNNES. 2017: 46(2): 35-40.

[4] Bayuntoro JT, Ngabekti S, Ridlo S. Keefektifan pembelajaran pencemaran lingkungan dengan mengaplikasikan pengajaran Quantum terhadap hasil belajar siswa. Journal of Lembaran Ilmu Kependidikan UNNES. 2015: 44(1): 56-62.

[5] Ichsan, I. Z., et.al. HOTS-AEP: Higher Order Thinking Skills from Elementary to Master Students in Environmental Learning. European Journal of Educational Research. 2019: 8(4): 935-942.

[6] Ichsan, I. Z., et.al. Implementation Supplementary Book of Green Consumerism: Improving Students HPTS in Environmental Learning. European Journal of Educational Research. 2020: 9(1): 227-237.

[7] Nurdyansyah, et al. Inovasipem belajar ansesuai Kurikulum 2013. Sidoarjo :Nizamia Learning Center; 2016.

[8] Sastromihardjo A.Media dan sum berpem belajaran. Article :UniversitasPendidikan Indonesia: 2008.

[9] Pranoto E,Sanjoto TB, Suroso. Efektivitas penggunaan media pembelajaran berbasis visual digital padapelajaran Geografi Kelas XI IPS di SMA Islam Sultan Agung 1 Semarang TahunAjaran 2015/2016.Journal Edu Geography. 2017: 5(1):39-47.

[10] Martanto C, Aji A, Parman S. Kajian kesiapsiagaan masyarakat dalam menghadapi bencana kebakaran di Kelurahan Kembangsari, Kecamatan Semarang Tengah. Journal of Edu Geography. 2017: 5(2): 10-17.

[11] Suharini E, Meri H, Kurniawan E. Local wisdom to mitigate volcano eruption in Sugihwaras Village Kediri. Journal of Disaster Advances. 2020: 13(1): 14-16.

[12] Sari YP. Perilaku siswa penggemar tayangan Korea di televisi pada siswa SMP Negeri 1 Jogorogo, Kabupaten Ngawi. Article : Universitas Negeri Sebelas Maret: 2014.

[13] Sriyanto, Kurniawan E, Suharini E, Syifauddin M. The development of a model of inducing nationalist-religious characters in Islamic boarding school in SMP 6 Kedungsuren Kendal Regency to Anticipate Radicalism among Young Generation. Proceeding of UNNES International Conference on Research Innovation and Commercialization 2018. 2019: 371-390.

[14] Sou CY. The effects of Korean Dramas on the students. Journal of Korean Tourism Organization of Taiwan Office, Taipei, Taiwan. 2015.

[15] Agatep EAL, et al. What is K-poppening? Behavior and academic performance of 3rd and 4th-year students of Lorma Colleges Special Science High School Students. Journal of Lorma Colleges Special Science High School, Manila, Filipina: 2014.

[16] Arikunto S. Prosedur penelitian, suatu pendekatan praktik. Jakarta : Rineka Cipta; 2013.

[17] Slameto. Belajardanfaktor-faktor yang mempengaruhinya. Jakarta: Rineka Cipta; 2010.

[18] Sudjana. Metode statistika. Bandung :Tarsito; 2004. 